\title{
Does post-bleaching fluoridation affect the further demineralization of bleached enamel? An in vitro study
}

\author{
Hande Kemaloğlu*, Hüseyin Tezel and Zeynep Ergücü
}

\begin{abstract}
Background: Topical fluoride agents have been shown to be the most effective method in treating demineralized enamel after in-office bleaching treatments. Thus, this study aimed to examine the effects of two different post-bleaching fluoridation agents: $1.5 \%$ titanium tetrafluoride $\left(\mathrm{TiF}_{4}\right)(9200 \mathrm{ppm})$ and $2.1 \%$ sodium fluoride ( $\mathrm{NaF}$ ) (9500 ppm), on the calcium loss of enamel after an acidic challenge.
\end{abstract}

Methods: Ten maxillary premolars were sectioned into four pieces and then divided into the following four groups: Group 1: Control, kept in artificial saliva, no treatment; Group 2: 38\% hydrogen peroxide (HP); Group 3: $38 \% \mathrm{HP}$ followed by 1.5\% $\mathrm{TiF}_{4}$; Group 4: $38 \% \mathrm{HP}$ followed by $2.1 \% \mathrm{NaF}$ solution. The specimens were subjected to demineralization for 16 days, refreshing the solution every 4 days; that is, on the 4th, 8th, 12th, and 16th days. Calcium ion $\left(\mathrm{Ca}^{2+}\right)$ concentration was determined by an atomic absorption spectrophotometer. Data were analyzed using Friedman and Wilcoxon tests $(p=0.05)$.

Results: The loss of $\mathrm{Ca}^{2+}$ in each of the test groups was compared with that of the control group, depicting that there was a statistically significant difference among the groups after 4, 8, 12, and 16 days and in total $(p<0.05)$. The calcium released from the fluoride-applied groups was lower when compared with the 38\% HP and control group. At the end of the 16th day, the total amount of calcium released from the $\mathrm{TiF}_{4}$-treated samples $(9.12 \mathrm{mg} / \mathrm{mL})$ was less than from the NaF-treated samples $(13.67 \mathrm{mg} / \mathrm{mL})(p<0.05)$.

Conclusions: Regarding the results of our in vitro study, the risk of further demineralization was significantly reduced with the use of $\mathrm{TiF}_{4}$ and $\mathrm{NaF}$ after bleaching with 38\% $\mathrm{HP}$. TiF 4 was found to be more effective in preventing $\mathrm{Ca}^{2+}$ release owing to acid attack when compared with $\mathrm{NaF}$. In the case of an intra-oral acidic exposure, the use of topical 1.5\% $\mathrm{TiF}_{4}$ and $2.1 \% \mathrm{NaF}$ agents might be beneficial after bleaching with 38\% HP.

Keywords: Bleaching, Demineralization, Sodium fluoride, Titanium tetrafluoride

\section{Background}

Bleaching has been accepted as one method of treating discolored teeth. Recently, novel in-office bleaching products that use high concentrations of hydrogen peroxide (HP) have made in-office treatments easier. However, the effects of these products on enamel are still an open issue and need to be clarified. When vital teeth are bleached, as a result of the direct contact between the bleaching agent and the outer enamel surface, the enamel surface of the tooth crown can be affected by high

\footnotetext{
*Correspondence: handedalgar@gmail.com

Department of Restorative Dentistry, Faculty of Dentistry, Ege University, Bornova 35100, Izmir, Turkey
}

levels of HP in bleaching agents, causing structural and morphological changes. There are many studies on the reduction in microhardness as well as the loss of calcium from bleached enamel [1-4]. Furthermore, some changes in bleached enamel were described as slightly erosive defects promoted by the bleaching agent [4-7].

The positive effect of highly concentrated fluoride products related to the inhibition of demineralization and erosion is well documented [8]. Different topical fluoride applications such as sodium fluoride $(\mathrm{NaF})$, acidulated phosphate fluoride, and stannous fluoride are widely used in promoting enamel remineralization. However, unlike the commonly used agents, it has been suggested in the 
literature that titanium tetrafluoride $\left(\mathrm{TiF}_{4}\right)$, may have a greater effect on enamel remineralization. Furthermore, the use of fluoride products after bleaching procedures has also been shown to be beneficial $[2,9,10]$. As topical fluoride is applied following bleaching, mineral loss is significantly reduced, microhardness is restored, and the resistance of enamel to demineralization is increased $[4,10,11]$.

Fluoride has been confirmed to remineralize lesions by increasing resistance to acid attack by forming a calcium fluoride layer to inhibit demineralization [9]. In addition, the formation of a glaze layer has been shown when enamel surfaces were treated with low $\mathrm{pH} \mathrm{TiF}_{4}[12,13]$. However, there are no data available in the literature on the preventive effect of these applications on further demineralization. Thus, the aim of this present study was to examine the effects of two different post-bleaching fluoridation agents $\left(\mathrm{NaF}\right.$ and $\left.\mathrm{TiF}_{4}\right)$ on the $\mathrm{Ca}^{2+}$ loss from enamel after an acidic challenge. The null hypotheses tested were: (1) no difference will be observed in $\mathrm{Ca}^{2+}$ release between the fluoridated and non-fluoridated groups of bleached enamel surfaces, after being subjected to acidic attack; thus, these fluoride agents will not affect the susceptibility of bleached enamel to further demineralization and (2) no differences in $\mathrm{Ca}^{2+}$ release will be noted between $\mathrm{NaF}$ - and $\mathrm{TiF}_{4}-$ treated enamel surfaces after being subjected to further demineralization following bleaching with 38\% HP.

\section{Methods}

This study was approved by the Ege University, Faculty of Medicine, Research Ethics Committee (19/10/2012) and written informed consent was received from participants.

\section{Sample preparation}

Ten maxillary premolars extracted for orthodontic purposes at Ege University, Faculty of Dentistry were selected for this in vitro study. All participants gave written consent prior to the extraction process. The extracted teeth were rinsed in tap water, and cleaned of plaque and debris with a dental hand piece and brush. The buccal, palatal, and occlusal surfaces were checked under a stereomicroscope, and teeth with enamel defects or cracks were rejected. Ten selected teeth were stored in $0.9 \% \mathrm{NaCl}$ and $0.1 \%$ thymol for 1 week at $4{ }^{\circ} \mathrm{C}$ to eliminate the reproduction of microorganisms, and then rinsed with distilled water. Each tooth was sectioned bucco-palatally into two halves with a diamond disc. These halves were then sectioned longitudinally into two parts, so that four specimens were obtained from each tooth. These specimens were later randomly assigned to one of the four groups, on the condition that each part of every tooth would be in one of the four different groups (Table 1). Then, the teeth were covered with wax except for the enamel surface.
Table 1 Test groups

\begin{tabular}{|c|c|c|c|c|c|}
\hline Groups & $\mathbf{N}$ & Bleaching agent & $\begin{array}{l}\text { Fluoride } \\
\text { application }\end{array}$ & $\mathrm{pH}$ & $\begin{array}{l}\text { F application } \\
\text { time }\end{array}$ \\
\hline 1 & 10 & No agent & --------- & & --------- \\
\hline 2 & 10 & $38 \%$ HP & ----- & & ------ \\
\hline 3 & 10 & $38 \%$ HP & $2.1 \% \mathrm{NaF}$ & $\sim 1.2$ & 1 minutes \\
\hline 4 & 10 & $38 \% \mathrm{HP}$ & $1.5 \% \mathrm{TiF}_{4}$ & $\sim 1.2$ & 1 minutes \\
\hline
\end{tabular}

\section{Bleaching procedure}

All specimens in three of the test groups were treated with a commercial in-office bleaching agent of 38\% HP (Opalescence Xtra Boost; Ultradent, South Jordan, UT, USA) according to the manufacturer's instructions. The untreated specimens in the fourth group were used as a control group and kept in artificial saliva $\left(0.7 \mathrm{mmol} / \mathrm{L} \mathrm{CaCl} 2,0.2 \mathrm{mmol} / \mathrm{L} \quad \mathrm{MgCl}_{2}, 4.0 \mathrm{mmol} / \mathrm{L}\right.$ $\mathrm{KH}_{2} \mathrm{PO}_{4}, 30.0 \mathrm{mmol} / \mathrm{L} \mathrm{KCl}, 20.0 \mathrm{mmol} / \mathrm{L}$ HEPES; $\mathrm{pH} 7.0$ ) during the test period $[14,15]$.

A thick layer $(\sim 1 \mathrm{~mm})$ of $38 \% \mathrm{HP}(\mathrm{pH} \cong 7)$ was applied to the enamel surfaces of the specimens in the test groups (Table 1). To achieve optimum effectiveness, the bleaching gel was stirred/agitated every $5 \mathrm{~min}$ and refreshed every $15 \mathrm{~min}$. The total time of application was $45 \mathrm{~min}$ per day. This procedure was repeated every other day for 3 days. After removing the whitening gel, the teeth were rinsed, dried, and kept in artificial saliva until the next procedure.

\section{Post-fluoridation process}

Two out of the three test groups were treated with two different fluoride agents with approximately the same concentrations; $1.5 \% \mathrm{TiF}_{4}$ (Aldrich Chem. Co, Milwaukee, WI, USA) $(\mathrm{pH}=1.2,9200 \mathrm{ppm})$ and $2.1 \% \mathrm{NaF}$ (Merck, Switzerland) $(\mathrm{pH}=1.2,9500 \mathrm{ppm})$. They were applied for $60 \mathrm{~s}$ using a pipette while the third test group was left untreated and kept in artificial saliva during the test period after the bleaching process.

\section{Demineralization process}

Immediately after the application of the bleaching and fluoride agents for the prescribed time, the specimens were rinsed with a water spray and dried with blasts of air. The enamel was then covered with standard "o"shaped wax so as to expose a standard round window area $(6.83 \mathrm{~mm}[2])$ and acetic acid buffered with $0.34 \mathrm{M}$ sodium acetate $(\mathrm{pH}=4)$ was used as a demineralization buffer. A calcium monohydrate salt $\left.\left[\mathrm{Ca}\left(\mathrm{H}_{2} \mathrm{PO}_{4}\right)_{2} \mathrm{H}_{2} \mathrm{O}\right)\right]$ was dissolved to obtain $10 \mathrm{mmol} / \mathrm{L} \mathrm{Ca}^{2+}$ and $20 \mathrm{mmol} / \mathrm{L}$ $\mathrm{PO}_{4}{ }^{3-}$ in the solution [16].

Each specimen was treated with $50 \mathrm{~mL}$ of solution in polyethylene test tubes. The specimens were demineralized in four consecutive periods over 4 days. At the end of the 4th day, each specimen was taken out of the test tube and placed in a new tube, which contained fresh 
buffer solution. The previous solutions were kept in their tubes to be tested afterwards for their $\mathrm{Ca}^{2+}$ concentration using an atomic absorption spectrophotometer (AAS), as performed in previous studies $[4,16]$.

Calcium analysis was undertaken with the AAS using $0.1 \mathrm{~mL}$ of each demineralization solution, which was diluted with $4.9 \mathrm{~mL}$ of distilled water. To prevent the interaction of magnesium and phosphate ions, 50,000 mg/L of lanthanum chlorine $\left(\mathrm{LaCl}_{2}\right)$ was added to each test tube to make up $10 \% \mathrm{LaCl}_{2}$ in each buffer solution. The same procedure was applied to blank (buffer) and standard solutions of calcium. The amount of calcium released from tooth to buffer was calculated by measuring the difference in $\mathrm{Ca}^{2+}$. The calcium concentration in the samples was detected with an AAS (Varian Spectra-10 plus AA; Varian, Melbourne, Australia) (wavelength: $422.7 \mathrm{~nm}$; slit $0.5 \mathrm{~nm}$ ). The calcium released to the buffer after the 4th, 8th, 12th, and 16th days were compared using Friedman and Wilcoxon tests.

\section{Results}

The $\mathrm{Ca}^{2+}$ concentrations of the samples were measured at the end of the 4th, 8th' 12th, and 16th days (Table 2, Figure 1). The loss of $\mathrm{Ca}^{2+}$ in the control, $38 \% \mathrm{HP}, 38 \%$ $\mathrm{HP}+\mathrm{NaF}$, and $38 \% \mathrm{HP}+\mathrm{TiF}_{4}$ groups were evaluated cumulatively every 4 days, and at the end of the 16th day, $15.07 \pm 1.81 \mu \mathrm{g} / \mathrm{mL}, 22.44 \pm 2.52 \mu \mathrm{g} / \mathrm{mL}, 13.67 \pm 1.86 \mu \mathrm{g} /$ $\mathrm{mL}$, and $9.12 \pm 2.40 \mu \mathrm{g} / \mathrm{mL}$ were obtained in total, respectively (Figure 2).

The loss of $\mathrm{Ca}^{2+}$ in each of the test groups was compared with that of the control group using the Friedman test. A statistically significant difference was observed among the groups after 4, 8, 12 and 16 days and in total $(\mathrm{p}<0.05)$. The Wilcoxon test was used to identify possible statistically significant differences between the groups.

After the demineralization process, there was significantly less $\mathrm{Ca}^{2+}$ released in the bleached/fluoride-treated groups $\left(38 \% \mathrm{HP}+\mathrm{NaF}\right.$ and $\left.38 \% \mathrm{HP}+\mathrm{TiF}_{4}\right)$ than in the bleached-only group ( $38 \% \mathrm{HP}$ ) and control group. When the $\mathrm{NaF}$ and $\mathrm{TiF}_{4}$-treated samples were compared, there were no significant differences between the amounts of $\mathrm{Ca}^{2+}$ released from the specimens after the 4 th, 8 th, and 16 th days $(p>0.05)$. However, at the end of the test period, the total amount of $\mathrm{Ca}^{2+}$ in the buffer solution was significantly less for the $\mathrm{TiF}_{4}$-treated samples than for the NaF-treated samples $(\mathrm{p}<0.05)$ (Tables 2 and 3 ). Thus, it might be suggested that $\mathrm{TiF}_{4}$-treated samples were more acid-resistant than NaF-treated samples.

\section{Discussion}

High concentrations of HP that promote enamel surface alterations soften the superficial layer of the enamel surface, increase surface porosity, and release more $\mathrm{Ca}^{2+}$ than low concentrations of HP and carbamide peroxide (CP) $[4,15,17]$. Thus, $38 \%$ HP has been recruited for the present study to investigate the $\mathrm{Ca}^{2+}$ released from the bleached enamel surfaces after an acidic challenge. With this designated high concentration, it was aimed to observe the maximum $\mathrm{Ca}^{2+}$ release after a further demineralization process.

Alterations in the inorganic component of hydroxyapatite might be an indicator of the changes in $\mathrm{Ca}^{2+}$ levels of enamel. Rotstein et al. [1] demonstrated that most bleaching agents may cause various changes in the

Table 2 Calcium ion $\left(\mathrm{Ca}^{2+}\right)$ release from the bleached specimens treated with $1.5 \% \mathrm{TiF}_{4}$ and $2.1 \% \mathrm{NaF}$ in $\mathrm{mm}$ ( $\left.\mathrm{mg} / \mathrm{ml}^{2}\right)$

\begin{tabular}{|c|c|c|c|c|c|c|c|}
\hline & $\mathbf{N}$ & & 4th day & 8th day & 12th day & 16th day & Total \\
\hline \multirow[t]{4}{*}{ Control group } & 10 & Mean & 3,59 & 3,2 & 3,72 & 4,55 & 15,07 \\
\hline & & Std dev & 0,54 & 0,59 & 1,23 & 0,89 & 1,81 \\
\hline & & Min. & 3,01 & 2,46 & 2,46 & 2,74 & 12,6 \\
\hline & & Max. & 4,93 & 4,38 & 6,58 & 5,75 & 18,36 \\
\hline \multirow[t]{4}{*}{$38 \% \mathrm{HP}$} & 10 & Mean & 5,75 & 5,18 & 5,56 & 5,95 & 22,44 \\
\hline & & Std dev & 1,6 & 1,52 & 0,71 & 0,37 & 2,52 \\
\hline & & Min. & 3,83 & 3,01 & 4,66 & 5,48 & 18,36 \\
\hline & & Max. & 7,95 & 8,5 & 6,85 & 6,58 & 27,68 \\
\hline \multirow[t]{4}{*}{$38 \% \mathrm{HP}+\mathrm{NaF}$} & 10 & Mean & 2,05 & 3,15 & 3,94 & 4,52 & 13,67 \\
\hline & & Std dev & 0,83 & 0,58 & 1,01 & 0,83 & 1,86 \\
\hline & & Min. & 0,82 & 2,19 & 2,46 & 3,29 & 10,68 \\
\hline & & Max. & 3,01 & 4,11 & 5,75 & 6,03 & 15,61 \\
\hline \multirow[t]{4}{*}{$38 \% \mathrm{HP}+\mathrm{TiF} 4$} & 10 & Mean & 1,15 & 1,94 & 2,66 & 3,37 & 9,12 \\
\hline & & Std dev & 0,92 & 1,54 & 0,63 & 0,48 & 2,4 \\
\hline & & Min. & 0 & 0 & 1,64 & 2,46 & 4,93 \\
\hline & & Max. & 2,46 & 4,11 & 3,56 & 3,83 & 11,5 \\
\hline
\end{tabular}




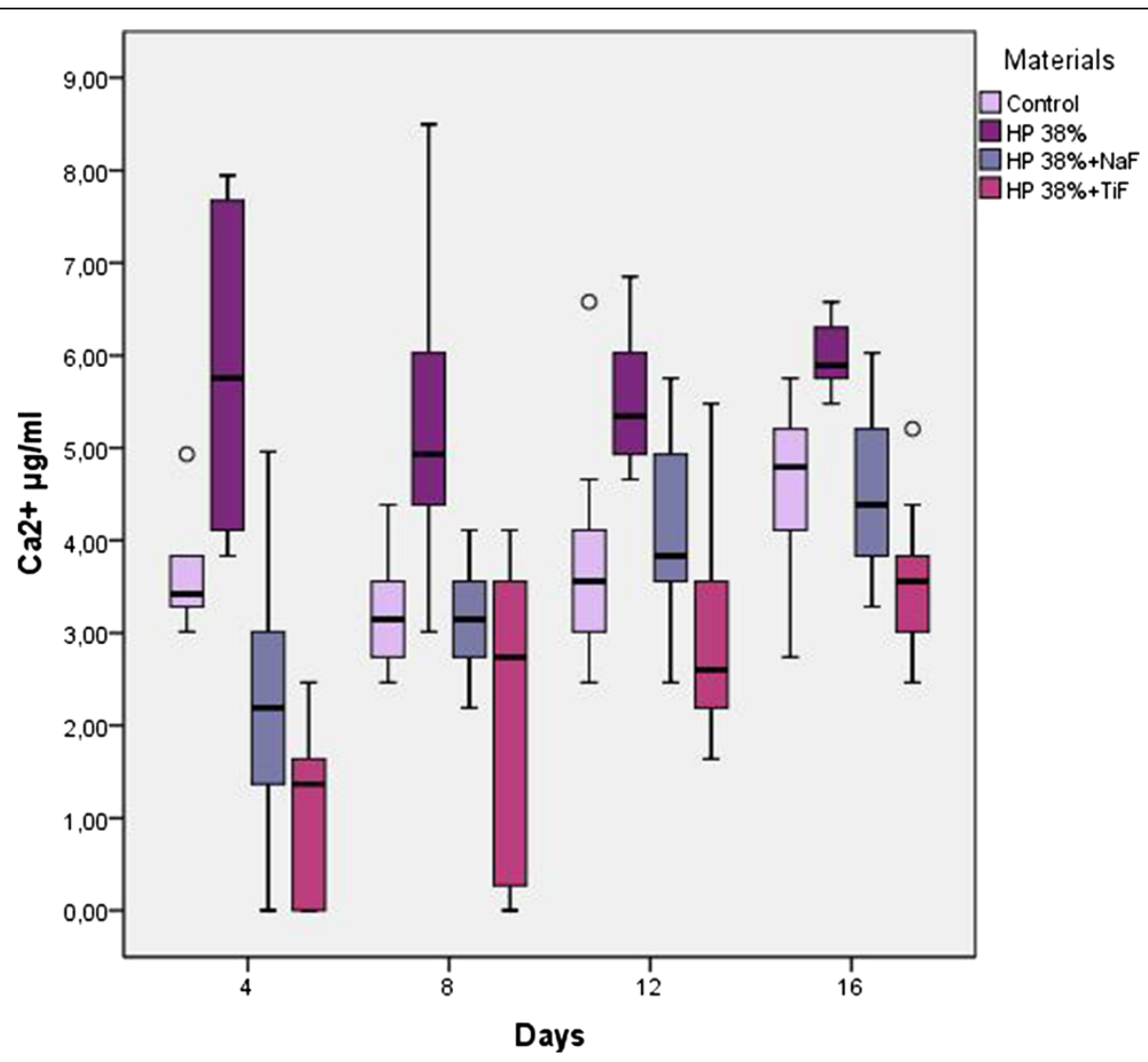

Figure 1 The calcium ion $\left(\mathrm{Ca}^{2+}\right)$ concentrations of the specimens measured at the end of the 4th, 8th, 12th, and 16 th days ( $\left.\mu \mathrm{g} / \mathrm{mL}\right)$.

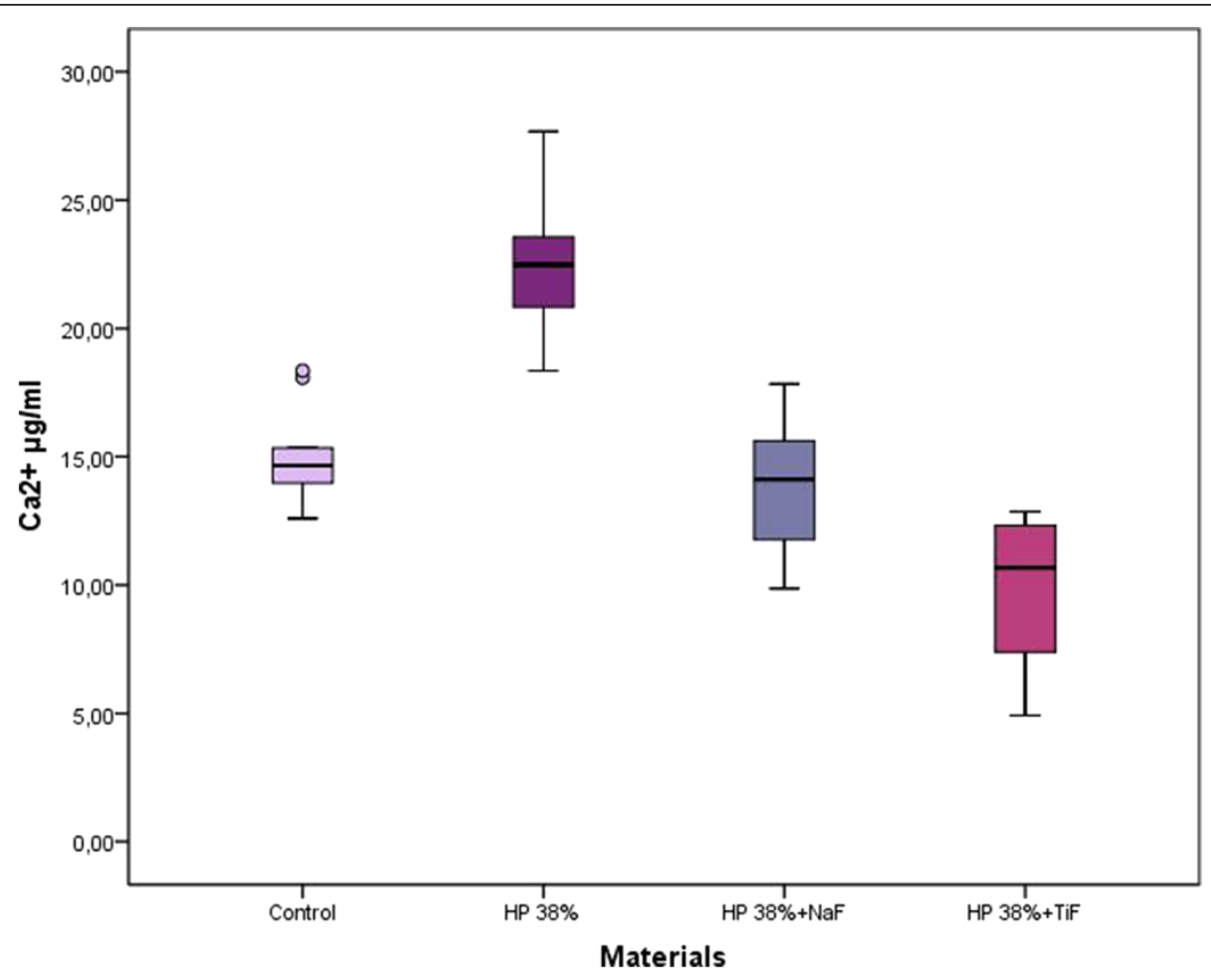

Figure 2 The total calcium ion $\left(\mathrm{Ca}^{2+)}\right.$ concentrations of the specimens measured at the end of the 16th day $(\mathrm{mg} / \mathrm{ml})$. 
Table 3 Statistical differences between test groups

\begin{tabular}{|c|c|c|c|c|c|}
\hline Materials & 4th day & 8th day & 12th day & 16th day & Total \\
\hline Control $\times 38 \% \mathrm{HP}$ & 0.007 & 0.017 & 0.022 & 0.005 & 0.005 \\
\hline Control $\times 38 \% \mathrm{HP}+\mathrm{NaF}$ & 0.036 & 0.798 & 0.444 & 0.878 & 0.721 \\
\hline Control $\times 38 \% \mathrm{HP}+\mathrm{TiF} 4$ & 0.005 & 0.059 & 0.167 & 0.059 & 0.005 \\
\hline $38 \% \mathrm{HP} \times 38 \% \mathrm{HP}+\mathrm{NaF}$ & 0.009 & 0.005 & 0.022 & 0.009 & 0.005 \\
\hline $38 \% \mathrm{HP} \times 38 \% \mathrm{HP}+\mathrm{TiF} 4$ & 0.005 & 0.013 & 0.007 & 0.005 & 0.005 \\
\hline $38 \% \mathrm{HP}+\mathrm{NaF} \times 38 \% \mathrm{HP}+\mathrm{TiF} 4$ & 0.074 & 0.241 & 0.047 & 0.059 & 0.017 \\
\hline
\end{tabular}

Statistically significant differences between the groups $(p<0.05)$.

No statistically significant differences $(p>0.05)$.

levels of calcium, phosphorus, and potassium in dental hard tissues; whereas Tezel et al. [4] demonstrated that $35 \%$ and $38 \% \mathrm{HP}$ caused $\mathrm{Ca}^{2+}$ loss from the enamel surfaces. In the present study, $\mathrm{Ca}^{2+}$ released from the enamel of specimens treated with $38 \%$ HP was significantly higher than the untreated control group $(\mathrm{p}<0.05)$. Based on the $\mathrm{Ca}^{2+}$ values, this result suggests that high concentrations of bleaching agents cause surface alterations after an acidic challenge.

The application of highly concentrated fluoride favors the formation of a $\mathrm{CaF}_{2}$-like layer [18]. This deposit is later dissolved, allowing fluoride to diffuse into the underlying enamel, saliva, or a plaque layer covering the tooth. It is assumed that some of the fluoride supports the remineralization of enamel. The results of a previous study confirmed that phosphates and proteins from saliva coated the calcium-fluoride layer on the enamel as a $\mathrm{pH}$-controlling reservoir. This layer acted to decrease demineralization and promote remineralization [19].

Al-Qunaian et al. [20] investigated the effects of whitening agents on caries susceptibility of human enamel and reported that no significant differences in caries susceptibility were observed between the untreated control specimens and those specimens treated with $10 \% \mathrm{CP}$, $20 \%$ CP with fluoride, and 35\% HP. There were no significant differences between the treated and controlled specimens for teeth treated with $10 \%$ CP or $35 \% \mathrm{HP}$. However, specimens treated with whitening gel containing 20\% CP with fluoride had significantly reduced caries susceptibility when compared with their untreated controls. It was claimed that this effect could be related to fluoride incorporation in $20 \% \mathrm{CP}$ gels containing fluoride, and the results were in agreement with laboratory studies that fluoride enhanced enamel remineralization.

In the present study, fluoride agents were applied to the bleached enamel and then subjected to further demineralization. When the test groups that were bleached with 38\% HP were compared, the decrease in $\mathrm{Ca}^{2+}$ loss of the $1.5 \% \mathrm{TiF}_{4}$-treated group was detected to be the lowest (Table 2). Regarding this result, it can be assumed that $\mathrm{TiF}_{4}$ may be effective in protecting the bleached enamel surface against acid attack. Interestingly, no $\mathrm{Ca}^{2+}$ release was detected from three specimens of $\mathrm{TiF}_{4}$ group during the first 4 days, and there was also no $\mathrm{Ca}^{2+}$ release from two specimens during the second 4-day interval (Table 2). We assume that this effect might be the result of the glaze formation after topical $\mathrm{TiF}_{4}$ application. It is known that formation of a glaze layer takes less than $10 \mathrm{~s}$ after the application of $\mathrm{TiF}_{4}$ [21]. The ability of $\mathrm{TiF}_{4}$ to strongly protect enamel against the action of acid is a synergistic effect of glaze formation and increased enamel fluoride content. The high fluoride content and great reduction in solubility found in $\mathrm{TiF}_{4}$-treated enamel suggests that a fluoride reaction with the enamel is involved [22]. In a previous study, Tezel et al. [16] reported that $\mathrm{TiF}_{4}$ was found to be more effective than Duraphat (NaF, $2.26 \% \mathrm{~F}$ ) or Elmex (amine fluoride, 1.25\% F) in preventing artificial enamel lesion formation. Attin et al. [23] reported that fluoridation was effective in increasing the resistance of enamel against demineralization by erosive substances. Similarly, the findings of this present study demonstrated that the resistance of bleached enamel against acid attack increased after $1.5 \% \mathrm{TiF}_{4}$ treatment.

The comparison of the $\mathrm{Ca}^{2+}$ losses from the test groups that were bleached with $38 \%$ HP revealed that the decrease in $\mathrm{Ca}^{2+}$ losses of the $2.1 \% \mathrm{NaF}$-treated group was also lower, indicating that $\mathrm{NaF}$ could also protect enamel surfaces against acid attack. When the NaF-treated group was compared with the control group, it was seen that the amount of $\mathrm{Ca}^{2+}$ lost from the $\mathrm{NaF}$ group was significantly different during the first 4 days $(\mathrm{p}<0.05)$ (Table 3). However, when the NaF-treated group was compared with the $38 \%$ HP group, the difference was statistically significant during the whole test period (16 days) $(\mathrm{p}<0.05)$.

However, when the effect of $\mathrm{NaF}$ treatment against acid attack was compared with $\mathrm{TiF}_{4}$ treatment, it was observed that its influence was not as strong as $\mathrm{TiF}_{4}$ (Table 3, Figure 1). Tveit et al. [24] assumed that complexes were formed between $\mathrm{TiF}_{4}$ and hydroxyapatite, based on a strong binding of the titanium compound and the oxygen atom of the phosphate group. Mundorff et al. [22] suggested that $\mathrm{TiF}_{4}$ acted with enamel both 
chemically, by decreasing enamel solubility, and physically, owing to the formation of a protective glaze on the enamel surface. van Rijkom et al. [25] compared the erosion-inhibiting effect of topical fluoride treatment based on the deposition of $\mathrm{CaF}_{2}$-like material using $1 \% \mathrm{NaF}$ and $4 \% \mathrm{TiF}_{4}$. It was concluded that the reduction of $\mathrm{Ca}^{2+}$ loss was more stable for $\mathrm{TiF}_{4}$ than for the NaF group, and the reduction appeared to be smaller with longer acid exposure times.

Generally, fluoride uptake of demineralized enamel is higher when compared with sound enamel [26]. It is assumed that the applied fluoride can easily penetrate through the porous structure of demineralized enamel and that can create a higher number of possible retention sites $[27,28]$. According to the results of one study [29], the bleached and fluoridated enamel was more resistant against erosive attacks than the bleached/unfluoridated and unbleached/unfluoridated enamel. In the present study, at the end of the test period, the total amount of calcium released from the bleached/fluoridated specimens was lower than the control group (unbleached/unfluoridated) and the difference was significant in $\mathrm{TiF}_{4}$-treated specimens $(\mathrm{p}<0.05)($ Table 3$)$. This result is noteworthy in that bleached and fluoridated teeth may be more resistant to acid attack than sound teeth. These results would need to be investigated with further studies.

In the last decade, there has been a growing interest in demineralization and remineralization studies because of the demand for minimally invasive treatment techniques. When scanning through the literature, we encountered a number of different techniques applied in these types of studies. In vitro demineralization using acid buffers and in vitro demineralization/remineralization using a $\mathrm{pH}$ cyling model are the most frequently used techniques that possess both advantages and disadvantages. It is important to choose the simplest and most practically appropriate model. Similar to the previous studies, we preferred using AAS for in vitro demineralization to observe the impact of fluoride agents on the $\mathrm{Ca}^{2+}$ loss following further demineralization. This method is a very sensitive but reliable method for calcium analysis, which avoids the interaction of other solutes [30,31]. It can be used with confidence to quantify erosion of both enamel and dentine, and their chemical analyses of mineral release [32-34].

Based on the results of the present study, the null hypothesis that states there would be no difference between the amount of $\mathrm{Ca}^{2+}$ released from the enamel surfaces that were treated with $\mathrm{NaF}$ and $\mathrm{TiF}_{4}$ after an acidic challenge was rejected. It was also shown that topical fluoride application decreased the amount of $\mathrm{Ca}^{2+}$ released from the 38\% HP-treated enamel surfaces after further demineralization. TiF had a significantly more pronounced effect than $\mathrm{NaF}$ in protecting enamel surfaces against acidic attack after bleaching with $38 \% \mathrm{HP}$.

\section{Conclusions}

It may be concluded that post-bleaching fluoride application may be beneficial in reducing the risk of demineralization caused by acid attack after bleaching processes and to remineralize the bleached enamel surfaces. In addition, $\mathrm{TiF}_{4}$-treated samples released less $\mathrm{Ca}^{2+}$ than NaF-treated samples, which indicates that $\mathrm{TiF}_{4}$ may be more effective than $\mathrm{NaF}$ in preventing damage from acid attack.

\section{Competing interests}

The authors declare that they have no competing interests.

\section{Authors' contributions}

HK participated in the design of the study, collected data, and was involved in drafting the manuscript. ZE analyzed the data, revised the manuscript, and was given approval for this version to be published. HT conceived of the study, participated in its design, and performed the statistical analyses. All authors read and approved the final manuscript.

\section{Acknowledgments}

We received no funding for this study.

Received: 5 May 2014 Accepted: 29 August 2014

Published: 6 September 2014

\section{References}

1. Rotstein I, Dankner E, Goldman A, Heling I, Stabholz A, Zalkind M: Histochemical analysis of dental hard tissues following bleaching. J Endod 1996, 22:23-25.

2. Lewinstein I, Fuhrer N, Churaru N, Cardash H: Effect of different peroxide bleaching regimens and subsequent fluoridation on the hardness of human enamel and dentin. J Prosthet Dent 2004, 92:337-342.

3. Al-Salehi SK, Wood DJ, Hatton PV: The effect of $24 \mathrm{~h}$ non-stop hydrogen peroxide concentration on bovine enamel and dentine mineral content and microhardness. J Dent 2007, 35:845-850.

4. Tezel H, Ertas OS, Ozata F, Dalgar H, Korkut ZO: The effect of bleaching agents calcium loss on enamel surface. Quintessence Int 2007, 38:339-347.

5. Pinto CF, Oliveira R, Cavalli V, Giannini M: Peroxide bleaching agent effects on enamel surface microhardness, roughness and morphology. Braz Oral Res 2004, 18:306-311.

6. Chen HP, Chang CH, Liu JK, Chuang SF, Yang JY: Effect of fluoride containing bleaching agents on enamel surface properties. J Dent 2008, 36:718-725

7. Ushigome TS, Takemoto M, Hattori M, Yoshinari E, Kawada, Oda Y: Influence of peroxide treatment on bovine enamel surface-Cross-sectional analysis. Dent Mater J 2009, 28:315-323.

8. Arends J, Christoffersen J, Christoffersen MR, Schuthof J: Influence of fluoride concentration on progress of demineralization in bovine enamel at pH 4.5. Caries Res 1983, 17:455-457.

9. Attin T, Kielbassa AM, Schwanenberg M, Hellwig E: Effect of fluoride treatment on remineralization of bleached enamel. J Oral Rehab 1997, 24:282-286

10. Attin T, Kocabiyik M, Buchalla W, Hannig C, Becker K: Susceptibility enamel surfaces to demineralization after application of fluoridated carbamide peroxide gels. Caries Res 2003, 37:93-99.

11. Bizhang M, Seemann R, Duve G, Römhild G, Altenburger JM, Jahn KR, Zimmer S: Demineralization effects of 2 bleaching procedures on enamel surfaces with and withoutpost-treatment fluoride application. Oper Dent 2006, 31:705-709.

12. Shrestha BM, Mundorff SA, Bibby BG: Enamel Dissolution: I Effects of Various Agents and Titanium Tetrafluoride. J Dent Res 1972, 5:1561-1566.

13. Büyükyilmaz T, Sen BH, Ogaard B: Retention of titanium tetrafluoride (TiF4), used as fissure sealant on human deciduous molars. Acta Odontol Scand 1997, 55:73-78.

14. Eisenburger M, Addy M, Hughes JA, Shellis RP: Effect of time on the remineralization of enamel by synthetic saliva after citric acid erosion. Caries Res 2001, 35:211-215. 
15. Lippert F, Parker DM, Jandt KD: Toothbrush abrasion of surface softened enamel studied with tapping mode AFM and AFM nanoindentation. Caries Res 2004, 38:464-472.

16. Tezel H, Ergücü Z, Önal B: Effects of topical fluoride agents on artificial enamel lesion formation in vitro. Quintessence Int 2002, 33:347-352.

17. Lewinstein I, Hirschfeld Z, Stabholz A, Rotstein I: Effect of hydrogen peroxide and sodium perboride on the microhardness of human enamel and dentin. J Endod 1994, 20:61-63.

18. Wiegand A, Attin T: Influence of fluoride on the prevention of erosive lesions-a review. Oral Health Prev Dent 2003, 1:245-253.

19. Rølla G, Saxegaard E: Critical evaluation of the composition and use of topical fluorides with the emphasis on the role of calcium fluoride in caries inhibition. J Dent Res 1990, 69:780-785.

20. Al-Qunaian TA: Microhardness of intracoronal dentin exposed to bleaching enamel. Oper Dent 2005, 30:265-270.

21. Skartveit $L$, Tveit AB, Tøtdal B, Selvig KA: Effects of TiF4 solutions on root surfaces in vitro after different application periods. Acta Odonto/ Scand 1989, 47:25-30.

22. Mundorff SA, Little MF, Bibby BG: Enamel dissolution: II. Action of titanium tetrafluoride. J Dent Res 1972, 51:1567-1571.

23. Attin $T$, Deifuss $H$, Hellwig E: Influence of acidified fluoride gel on abrasion resistance of eroded enamel. Caries Res 1999, 33:135-139.

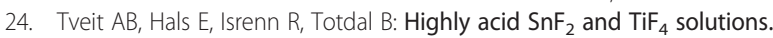
Caries Res 1983, 17:412-418.

25. van Rijkom H, Ruben J, Vieira A, Huysmans MC, Truin GJ, Mulder J: Erosioninhibiting effect of sodium fluoride and titanium tetrafluoride treatment in vitro. Eur J Oral Sci 2003, 111:253-257.

26. Øgaard B: Effects of fluoride on caries development and progression in vivo. J Dent Res 1990, 69:813-819.

27. Attin T, Albrecht K, Becker K, Hannig C, Wiegand A: Influence of carbamide peroxide on enamel fluoride uptake. J Dent 2006, 34:668-675.

28. Arnold WH, Haase A, Hacklaender J, Gintner Z, Bánóczy J, Gaengler P: Effect of $\mathrm{pH}$ of amine fluoride containing toothpastes on enamel remineralization in vitro. BMC Oral Health 2007, 17:7-14.

29. Burgmaier GM, Schultze IM, Attin T: Fluoride uptake and development of artificial erosions in bleached and fluoridated enamel in vitro. $J$ Oral Rehabil 2002, 29:799-804

30. Willis JB: Determination of calcium and magnesium in urine by atomic absorbtion spectroscopy. Anal Chem 1961, 33:556-559.

31. Trudeau DL, Freier EF: Determination of calcium in urine an serum by atomic absorption spectrophotometry (AAS). Clin Chem 1967, 13:101-114.

32. Grenby TH, Mistry M, Desai T: Potential dental effects of infants' fruit drinks studied in vitro. Br J Nutr 1990, 64:273-283

33. Hara AT, Zero DT: Analysis of the erosive potential of calcium-containing acidic beverages. Eur J Oral Sci 2008, 116:60-65.

34. Schlueter N, Hara A, Shellis RP, Ganss C: Methods for the measurement and characterization of erosion in enamel and dentine. Caries Res 2011, 45(suppl):13-23.

doi:10.1186/1472-6831-14-113

Cite this article as: Kemaloğlu et al:: Does post-bleaching fluoridation affect the further demineralization of bleached enamel? An in vitro study. BMC Oral Health 2014 14:113.

\section{Submit your next manuscript to BioMed Central and take full advantage of:}

- Convenient online submission

- Thorough peer review

- No space constraints or color figure charges

- Immediate publication on acceptance

- Inclusion in PubMed, CAS, Scopus and Google Scholar

- Research which is freely available for redistribution

Submit your manuscript at www.biomedcentral.com/submit
C Biomed Central 